\title{
INVESTIGATING THE IMPACT OF THE AGE, GENDER AND YEARS LEARNING ENGLISH ON LEARNING STYLES PREFERENCES
}

\author{
Zahra Naimie ${ }^{1}$ \\ Norasmatul Akma ${ }^{2}$ \\ Rana Ahmed Abuzaid \\ Revatde Nadarajan
}

\begin{abstract}
Demographical factors may have an impact on learning and teaching styles across the continents. This study was to explore whether demographical factors namely age, gender and English learning experience are related to the learning style preferences of English Major Students from the foreign languages faculty in Iran. The sample for this study comprised of 310 English Major Students. In this study, quantitative approach was used in the collection of the data .The instruments used in this study included the Index of Learning Styles Inventory by Felder and Soloman (2006) and Oxford (1990). The results of the study revealed that except for Learning Style Pair 2 (LSP2) (Sensing/Intuition), all the other learning styles pairs were not related to demographical factors.
\end{abstract}

Keywords: Demography, Learning, Age, learning experience

\section{INTRODUCTION}

Today, one of the focuses of research in teaching and learning is exploration of the learners' strategies when they are involved in the learning task.Educators have noticed that some students prefer certain ways of learning more than others; this preference is referred to as the learning style that can aid teachers in the successful teaching plan (Baumgartner, 2001). In other words, learning styles can be defined as the way the individual prefers to go about learning.

The notion of learning style needs to be clarified, because in most situations learning styles, learning strategies and learning preferences are used interchangeably. Smith and Dalton (2005) defined learning style as "a distinctive and habitual manner of acquiring knowledge, skills or attitudes through study or experience" (p. 7). Riding and Rayner (1998) (quoted in Hillberg \& Tharp, 2002, p. 1) defined learning styles as individual collections of learning strategies (manners in which learning tasks are responded to) integrated with cognitive styles (the way the information is stored and represented). Therefore it can be concluded that students should understand that sometimes their learning style might or might not be the best one for the tasks given and because of that, some degree of style "stretching" or style flexing is required. Reid (1995) stated that learners need to be aware in order to be successful learners; sometimes they should "stretch" their preferred learning style. Students learn, see, interpret and understand differently (Teele, 2006; Zacharis, 2011).

Kinshuk et al. (2009) highlighted the fact that even though students learn differently but they are able to achieve higher with the style they are comfortable with. The information on students' learning styles can be useful when the learning style implementation in adult education is related to the teachers' learner style versatility at different levels and in

\footnotetext{
${ }^{1}$ Senior lecturer, Department of Curriculum and Instructional Techonogy, Faculty of Education, University of Malaya, Malaysia.

${ }^{2}$ Senior lecture dental, Faculty of dentistry, University of Malaya, Malaysia.
} 
different subjects (Nielsen, 2005).Learning styles have been widely defined but in this paper, the definition of learning styles by Felder and Soloman (2006) is adapted whereby learning style classified students under four categories based on their preferences. The categories are namely: Active / Reflective, Sensing / Intuition, Visual / Verbal, and Sequential / Global.

The idea of creating the lessons that apply 'one-size-fits-all' approach for teaching and learning cannot be applied any more. The 21 st century learners have varied needs and preferences where their learning environment are concerned since the technology integration had happened.They would require certain learning styles preferences resulted from technology advancement. (Bennett, Maton, \& Kervin, 2007). Researches (Putintseva, 2006; Wu, 2010; Park, 2002; Xiao \& Tianjin, 2006; Jhaish, 2010; Karthigeyan \& Nirmala, 2013) have confirmed the fact that learning stylesis one of the vital elements to be considered where learning and teaching improvement is discussed. Learning styles preferences may be influenced by several factors which these factors include age, gender, educational level, proficiency level, study field, belief, attitudes and motivation, prior knowledge of learning styles, content, country's education system and teachers teaching styles (Dunn, Dunn, \& Price, 1979; Ehrman \&Oxford, 1995; Reid, 1987).

In terms of age, Reid (1987) identified that the learning style preferences for older students were mainly towards visual and auditory modalities. This is supported by Other studies (Cherry, 1981; Dunn, Price, \& Sanders 1981; James \& Galbraith, 1985; Keefe, 1987; Rossi-Le, 1989) which shown that visual style has dominated among adult learners. In addition,Barbe and Milone (1981) identified shifts that occur in learning style preferences as an individual matures. In the primary level, the learning style strengths are more defined with the dominant one being the auditory. Research regarding the impact of the gender on learning styles has grown recently.

Some studies suggested that Gender differences may have an impact on individual's preferences in learning (Yi, Hui, \& Jasmine, 2011;Muralidhara, Nordin, \&Mohmad Nasir, 2013; Zainora et al., 2011). This can be explained due to the fact that there is a discrepancy in number university enrolment betweengenders (Nadia et al., 2010; Sudeera, 2011). Several studies such as Nadia et al., 2010; Vaseghi, Ramezani, \& Gholami, 2012; Adi Afzal, 2011; Kashefi et al. 2012 have zoomed into the impact of the gender on learning that results pointed out the "mix finding" except Vaseghi et al. (2012) and Nadia et al. (2010) which confirmed that there is a gender discrepancies where student learning preferences are referred. On contrary, Kashefi et al. 2012) found that there is no relationship between gender and learning styles preferences. Tatarintseva, 2002; Llach \& Gallego, (2012) highlighted that more research are to be encouraged in this area as there are still grey area relating gender and learning style.

Nadia et al. (2010) stated that tailoring togender varsity in learning environment will establish a proper solution to "gender gap in education." Finding reported that there is no significant gender varsity in LSPs. Zokaee, Zaferanieh, and Naseri (2012) study the impacts of perceptual learning styles and gender on Iranian English as Foreign Language (EFL) learners' vocabulary learning strategies selection. Their finding indicated that the gender has no impact on learner's vocabulary strategies selection.

Where educational background concerns, Reid (1987) reported that graduate students had a greater tendency for visual learning than undergraduates did. The learner's academic background and experience were not specified in his study. Politzer and MacGroarty (1985) believed that previous educational experiences have an impact on cognitive styles and classroom behaviours of the learners from other cultures. A study on adult native 
speaker learners of English showed that highly educated adults self-select learning style preference with greater accuracy (Cherry, 1981) and that their mean scores in all the dominant learning modes are higher (James \& Galbraith, 1985). Jacobs (1990) utilized several learning style instruments with African-American secondary school students and found a correlation between learning style preferences and achievement level. Based on his findings, high achiever learners showed higher usage of multiple learning styles. The findings of many other researchers suggest that students with higher language proficiency had preferences for visual learning style (Cherry, 1981; James \& Galbraith , 1985; Keefe, 1987; Rossi-Le, 1989).

Studies on US learners who showed a shift towards visual learning styles along with learner maturity and ability to read (Keefe, 1987; Price, Dunn, \& Sanders, 1979). Rossi-Le (1989) explored the relationship between kinaesthetic learning styles preferences and the subject's proficiency and work history. According to these findings the more proficient the English learners the more they preferred learning through interactive method and direct experiences with the language.

Where From the first through the sixth grade, visual and kinaesthetic preferences dominant but high school age students show more tendencies towards the visual and auditory. According to researchers, this shift represents a change in the environment as students learn to read (visual) and write (kinaesthetic). The relationship between the educational level and learning styles preferences have been pictured in Reid's study as well as an earlier one.

Learning experience is another significant factor which is claimed to have an influence on the use of language learning style. Fazzaro and Martin (2004) agreed that learning styles development among the learners can be established from their past life experiences and society need. Tuan, (2011) \& Said and Ghani (2009) zoomed to the relationship between the language learning experience and language learning styles They have also stated that when the learner is equipped with more experiences in EFL environment, they are aware to select the most suitable strategies which match their learning styles preferences.

The Iranian education system requires students to learn and consider English as one of the foreign languages. The focus for the EFL learners in primary and secondary schools is primarily on English for communication, unlike in higher degree education such as institutes and universities where the focus goes beyond the ability to communicate effectively. For this level of learners, regardless of their major, the amount of knowledge that they need to process increases daily with the sources being in the English language. Some of these students have to attend private classes to improve their EFL skills. In many cases, the classes will not provide what the students need, so the student's participation in these classes will not lead to success.

The objective of this study is to investigate EFL learners' learning styles and the relationship of three factors, namely, Age, Gender and learning on Learning Styles Preferences. Specifically, the study was designed to address the following questions:

1) What are the learning style preferences of Iranian learners?

2) To what extent gender, age, and learning experience have an impact on learners learning style preferences?

\section{METHODOLOGY}

The research method used for this study is the quantitative approach by using the survey. Researchers used the survey to obtain the variety of the students' learning styles and also 
used the questionnaires to obtain some information regarding the learner's age, gender and English learning experiences. Demographic information was obtained to explore whether they have any impact on learners learning styles preferences or no?

However, this study will assist the EFL learners develop into successful learners through utilizing learning style preferences more efficiently and effectively.

\section{Instruments}

The following are the steps taken by the researcher in this study:

Step one: identification of learner's information through demographic questions using:

a) Demography questions (part A)

Step two: identification of students' learning styles by conducting the survey:

b) Learning style survey, using the Felder and Soloman Learning Style Inventory (ILS). (part B)

The Index of Learning Styles (ILS) questionnaire developed by Felder and Soloman based on the Felder-Silverman Learning Style Model was used in this study to assess students learning preferences. In this instrument there are four dimensions that are Active/reflective, Sensing/Intuitive, Visual/Verbal and Sequential/Global. Active/reflective: refers to the differences between Learning by trying something and learning by contemplation Sensing/Intuitive: refers to the differences between learning by knowing facts or details and learning by knowing the relationship. Visual/Verbal: refers to the differences between learning more through pictures and figures and also reading and hearing. Sequential/Global: refers to learning by following logical steps and learning to see the bigger picture. Previously there were 5 dimensions, including Inductive/Deductive, based on Felder and Silverman (1988) but this dimension has been dropped from the index.

The questionnaire that was applied in this study consists of two sections; Section A and B. Section A seek respondents' demographic data such as gender, age, ethnicity, previous learning experienceand English achievement level. Section B consisted of 44 questions from the ILS questionnaire. The questions were merged into the first part of the main questionnaire(ILS) to identify the extent and percentage of the ESL students' preferences in learning style vary by gender,ethnicity, previous learning experience and English achievement level in the four dimensions of ILS that are named LSPs consst of LSP1()LSP2()LSP3()LSP4(). However not all demographic factors obtained will be used for the purpose of the analysis in this study.Subjects for this study were from four undergraduate classes in the faculty of foreign languages in the main campus of one of the universities in Iran.

\section{Participants}

The total initial participants of this study consisted of 310 university students in the main campus of one of the universities in Iran. The participants involved in this study are majoring in English as a Foreign Language (EFL); furthermore, they were from different age groups. This group of students can be categorized mainly as medium users of the English language because they have chosen English as their major. English language majors are expected to be fluent in both spoken and written English. The sample age range was between 20 to 40 years old.

All participants had at least 7 years of formal education in English. The participants were also enrolled in speaking courses, all of which are required courses in order to attain the 
bachelors of English degree. These courses are designed in order to improve their speaking ability. Students from this academic discipline were chosen to ensure a certain level of language proficiency (intermediate or above) required for discourse markers to be noticed and to show their facilitating effect (Perez \& Macia, 2002).

\section{Data analysis}

All responses from the questionnaires survey statistically was analysed and organized to offer answers to the research questions. Descriptive and inferential analysis of the quantitative data was evaluated by using the Statistical Package for the Social Sciences (SPSS).

Descriptive statistics such as means, standard deviations, frequencies, and percentages was applied to analyse the data for variables including gender, age, learning styles and teaching styles.

\section{Finding and discussion}

The research reports the preferred learning styles of the 310 EMS participants based on their responses to the Felder and Soloman (2006) learning styles inventory. As the second step, the impact of gender, age and years of learning

English on learning style preferences was explored.

This section will answer research question 1 that discusses what are the learning style preferences among the learners in Iran. It is related to the patterns of the learning style preferences among the students. The results in Tab. 1. depict the learners' style patterns in a university setting in Iran.Finding indicated there is no significant difference between the learners choice when the 4 dimension of the learning styles are concerned. However the dimension that was highest rated by the learners was LSP2, LSP3,LSP1 and LSP4.

In order to answer research question two, chi square analysis was done.The findings also showed that there is no significant relationship between age and learners' learning styles preferences in LSP1: .47, LSP3: .81, LSP4: .50, but on the other hand there is a significant relationship between the LSP2: .058 and Age. The results indicated that there is no significant relationship between learning style preferences and gender in all four dimensions of the Felder and Soloman learning styles inventory (LSP1: .47, LSP2: .70, LSP3: .43, LSP4: .27) for this sample.

It is also indicated that there is no significant relationship between years learning English and learners' learning styles preferences in LSP1: .64, , LSP4: .85 but on the other hand there is a significant relationship between the LSP2: .015 LSP3 :.025 and years of learning English. 
Tab. 1. Frequencies and percentages of the LSP's dimensions

\begin{tabular}{|l|l|l|l|}
\hline \multicolumn{2}{|l|}{ Dimensions } & Frequency & Percentage \\
\hline \multirow{2}{*}{ Dimension 1 (LSP1) } & Active & 157 & 50.6 \\
\cline { 2 - 4 } & Reflective & 153 & 49.4 \\
\hline \multirow{2}{*}{ Dimension 2 (LSP2) } & & $\mathbf{3 1 0}$ & $\mathbf{1 0 0 \%}$ \\
\hline & Sensing & 236 & 76.1 \\
\cline { 2 - 4 } & Intuitive & 74 & 23.9 \\
\hline \multirow{2}{*}{ Dimension 3(LSP3) } & & $\mathbf{3 1 0}$ & $\mathbf{1 0 0} \%$ \\
\hline & Visual & 210 & 67.7 \\
\cline { 2 - 4 } & Verbal & 100 & 32.3 \\
\hline Dimension 4(LSP4) & & $\mathbf{3 1 0}$ & $\mathbf{1 0 0} \%$ \\
\hline & Sequential & 150 & 48.4 \\
\cline { 2 - 4 } & Global & 160 & 51.6 \\
\hline & & $\mathbf{3 1 0}$ & $\mathbf{1 0 0} \%$ \\
\hline
\end{tabular}

Analysis of the dominant learning styles of EFL students showed the following results. Students' preferred learning styles were reported as an active, sensing, visual and global style. However, the dominant learning style of the EFL lecturers were reported as active, sensing, visual and in the last dimension the preferences have been equally distributed between the Sequential and Global dimensions.

Based on the results, the students expressed major preferences for active learning styles; active learners like to comprehend the new information and be involved physically in the class activities. They like to study with one or more students in a group. Class interaction is considered as another success factor for these kinds of learners. To recall the information learned in the class, these active learners need to work with one or more students to understand the subject matter, whereas reflective learners learn best when they study alone. The reflective learners obtain information easily if they are left alone to work on their own and in a very quiet environment and they like to study alone.

Another preference was the sensing learning style. Sensing learners like to be more practical, discover the possible chances, solve problems by established methods, like innovation and love to experience the facts through hands-on experience. They learn best when they have hands-on experience through trial and error. For these types of learners, it is recommended that the lecturer use problem solving activities and let them feel the situation and ask them for the possible solution, whereas for learners such as visual which are considered as a preference in the third dimension, they learn best by looking at the information, reading, observing and thus learn best through visual aids such as charts, schematics, diagrams or any type of visual presentation. Writing notes in the class will assist them to remember the material they have to learn.

Finally, for the preferences in the last dimension, the learners' preferences were equally distributed; it means the students have equal preferences for both ends of the dimension. Sequential learners are good in following the logical order of the information but they are unable to link the information with the different aspect of the subject learned in a class. On the other hand, the sequential learners are more comfortable with the random information; it is difficult for them to explain to others what they have learned but they understand the 
concept and the subject matter clearly. For theses types of learners, the lecturers must use a kind of narrative activity to let them express what they understand and get them to be actively involved in the class.

The results of this study indicated that there is no significant relationship between learning style preferences and gender in all four dimensions in the Felder and Soloman inventory (LSP1: .47, LSP2: .70, LSP3: .43, LSP4: .27 ). The findings showed that there is no significant relationship between age and learners' learning styles preferences in LSP1: .47, LSP3: .81 , LSP4: .50 but on the other hand there is a significant relationship between the LSP2: .058 and Age. This study also found no significant relationship between years learning English and learners' learning style preferences in LSP1: .64, LSP4: .85 but on the other hand there is a significant relationship between the LSP2: .015 LSP3: .025 and years of learning English.

Therefore, the tasks in this study were two- fold. The first was to find a way to determine a subject's learning styles preferences along the dimensions of active- reflective, sensingintuition, visual-verbal and sequential-global. The second was to assess the impact of factors such as age, gender, number of years learning English language.This study only discussed a few demographical factors and their impact on learning style preferences. The factors discussed in this study were age, gender and duration of the years learning English. It is recommended to investigate the impact of the more demographic factors on student learning preferences to see the variety of the finding.

\section{REFERENCES}

Ahmad, A. (2011). Language learning style preferences of Low English proficiency (LEP) students in a tertiary institution. Malaysian Journal of ELT Research, 7(2), 33-62.

Barbe, R., \& Milone, M. (1981, February).What we know about modality strengths. Educational Leadership,378-380.

Baumgartner, L. (2001).An update on transformational learning. In S. B. Merriam (Ed.), The new update on adult learning theory: New directions in adult and continuing education, no. 89. San Francisco: Jossey-Bass.

Bennett, S., Maton, K. \& Kervin, L. (2008). The 'digital natives' debate: A critical review of the evidence. British Journal of Educational Technology, 39,775-786. doi: 10.1111/j.1467-8535.2007.00793.x

Cherry, C. E. (1981). The measurement of adult learning styles: Perceptual modality[Abstract]. Unpublished doctoral dissertation, University of Tennessee, Knoxville. Dissertation Abstracts International, 42(09A), 3852.

Cherry, C. E. (1981). The measurement of adult learning styles: Perceptual modality[Abstract]. Unpublished doctoral dissertation, University of Tennessee, Knoxville. Dissertation Abstracts International, 42(09A), 3852.

Dunn, R., Dunn, K., \& Price, G. (1979). Identifying individual learning styles. InStudent learning styles: Diagnosing and prescribing programs. Reston, VA: National Association of Secondary School Principals.

Dunn, R., Price, G.E., \& Sanders, W. (1981). Reading achievement and learning styles. The Clearing House, 54(5), 223-226.

Ehrman, M.,\& Oxford, R.(1995). Cognition plus: Correlates of language learning success. The Modern Language Journal, 79(1), 67-89. 
Fazarro, D., \& Martin, B. (2004). Comparison of learning style preferences of agriculture, human sciences, and industrial technology students at a historically black university. The Workforce Education Forum. Retrieved March 25, 2009, from http://www.voced.edu.au/content/ngv29409

Felder, R., \& Soloman, B. (2006). Index of Learning Styles (ILS). Retrieved from http://www2.ncsu.edu/unity/lockers/users/f/felder/public/ILSpage.html

Hillberg,R.S., \& Tharp,R.G. (2002).Theoretical perspectives, research findings, and classroom implications of the learning styles of American Indian and Alaska Native students. Retrieved from www.individualresearch.nrt/edorc02-03.htm

Jacobs, R.L. (1990). The social behaviors of field indeoendent and field dependent students in a Personalized System of Instruction course. Unpublished Doctoral Dissertation, Indiana University.

James, W. B., \& Galbraith, M. W. (1985). Perceptual learning styles: Implications and techniques for the practitioner. Lifelong Learning: An Omnibus of Practice and Research, 8(4), 20-23.

Jhaish, M. A. (2010). The relationship among learning styles, language learning strategies, and the academic achievement among the English majors at Al-Aqsa University (Master's thesis).The Islamic University. Retrieved from http://libraty.iugaza.edu.ps/thesis/90213.pdf

Karthigeyan, K., \&Nirmala, K. (2013). Learning style preference of English language learners. Educationia, 2(1), 134-140.

Kashefi, H., Ismail, Z., Yusof, Y. M., \& Rahman, R. A. (2012). Supporting students mathematical thinking in the learning of two-variable functions through blended learning. Procedia-Social and Behavioral Sciences, 46, 3689-3695.

Keefe, J. W. (1987). Theory and practice. Reston, VA: National Association of Secondary School Principals.

Kinshuk, M. C., Graf, S., \& Yang, G. (2009). Adaptivity and personalization in mobile learning. Technology, Instruction, Cognition and Learning (TICL), 8, 163-174.

Llach, M. D. P. A., \&Gallego, M. T. (2012).Vocabulary knowledge development and gender differences in a second language. Elia: Estudios de lingüísticainglesaaplicada, (12), 45-76.

Man-fat Wu, M. (2010). An exploratory study of the language-learning style preferences and language-learning motivation of ESL learners at a vocational education institute in Hong Kong. Electronic Journal of Foreign Language Teaching, 7, 1, 222-238.

Muralidhara, D. V., Nordin Simbak, \&Mohmad Nasir Mat Nor (2013). Learning style preferences of preclinical medical students in a Malaysian university. South-East Asian Journal of Medical Education, 7(1), 23.

Dahlan, N. A., Noor, M., Azian, N., Mustafa, S., Muzlia, S., Said Hashim, K., \& Zulkifli, V. (2010). Exploring the gender gap in achievement in Malaysia: A case for learning styles. International Journal of Learning, 17(4), 15-28.

Nielsen, T. (2005). Learning styles of Danish university students - do they differ according to subject of study at the start of the first academic year? - Is there a subject specific socialization effect of one year of higher education? Development of and research by means of The Danish Learning Styles Inventory (D-LSI) based on Sternberg's theory of mental self-government, Unpublished doctoral dissertation, The Danish University of Education, Copenhagen, Denmark. 
Park, C. C. (2002). Crosscultural differences in learning styles of secondary English learners. Bilingual Research Journal, 26(2), 443-459.

Perez, M. A., \& Macia, I. A. (2002). Metadiscourse in lecture comprehension: Does it really help foreign language learners? Allantis, 14(2), 3-21.

Politzer, R. L., \& McGroarty, M. (1985). An exploratory study of learning behaviors and their relationship to gains in linguistic and communicative competence. TESOL Quarterly, 19(1), 103-123.

Putintseva, T. (2006). The importance of learning styles in ESL/EFL. The Internet TESL Journal, 12(3).

Reid, J. (1995). Learning styles in the ESL/EFL classroom. Boston: Heinle \& Heinle.

Reid, J. M. (1987). The learning style preferences of ESL students. TESOL Quarterly, 21(1), 87111.

Riding, R., \& Rayner, S. (1998). Cognitive styles and learning strategies: Understanding style differences in learning and behavior. London: David Fulton.

Rossi-Le, L. (1989). Perceptual learning style preferences and their relationship to language

Said, J., \& Ghani, E.K. (2009). The effect of course selection and course experience on students' learning style preference. European Journal of Social Sciences, 10, 1, 74-84.

Smith, P., \& Dalton, J. (2005). Accommodating learning styles: Relevance and good practice in VET. ANTA.Retrieved from http://www.ncver.edu.au/research/proj/ nr3013.pdf

Ishan Sudeera, A., \& Tham, C. Y. (2011). Implementation of Facebook Study Groups as Supplements for Learning Management Systems (LMS) in Adult ODL Environments. Asian Association of Open Universities Journal, 7(1), 1-11.

Tatarintseva, A. (2002). The influence of the gender factor to the learning styles of secondary students in the process of language learning. Studies about languages, 2, 63-68.

Teele, L. (2006). The Impact of integrated study skills and critical thinking on student achievement. United States: ProQuest Information and Learning Company.

Tuan, L. T. (2011). EFL learners' learning styles and their attributes. Mediterranean Journal of Social Sciences, 2(2), 299-320. university context. The Asian EFL Journal, 8(4), 74-99.

Vaseghi, R., Ramezani, A. E., \& Gholami, R. (2012). Language learning style preferences: A theoretical and empirical study. Advances in Asian Social Science, 2(2), 441451.

Wu, M. M. F. (2010). An exploratory study of the language-learning style preferences and language-learning motivation of ESL learners at a vocational education institute in Hong Kong. Electronic Journal of Foreign Language Teaching, 7(2), 222-238.

Xiao, L. X. (2006). An empirical study of learning needs of Chinese English majors in a

Xiao, L., \& Tianjin, P. R. (2006).Bridging the gap between teaching styles and learning styles: A cross-cultural perspective. TESL-EJ, 10(3), 1-15.

Yi, W. C., Hui, H. W., \& Jasmine, S. (2011). Relationship between learning styles and Content Based Academic Achievement among Tertiary Level Students. In The Enhancing Learning: Teaching and Learning Conference.

Zacharis, N. Z. (2011), The effect of learning style on preference for web-based courses andlearning outcomes. British Journal of Educational Technology, 42, 790-800. 
Zainora, M., et al. (2011). Learning styles preferences among third year optometry students of Universiti Kebangsaan Malaysia. Procedia-Social and Behavioral Sciences, 18, 384-387.

Zokaee, S., Zaferanieh, E., \& Naseri, M. (2012). On the impacts of perceptual learning style and gender on Iranian undergraduate EFL learners' choice of vocabulary learning strategies. English Language Teaching, 5(9), p138. 